\title{
Monetary Union and Bilateral Trade among CFA Franc Zone Member Countries: An Empirical Analysis
}

\author{
Gnanderman Sirpe \\ Université Ouaga II, Ouagadougou, Burkina Faso \\ Email: gsirpe@yahoo.fr
}

How to cite this paper: Sirpe, G. (2019) Monetary Union and Bilateral Trade among CFA Franc Zone Member Countries: An Empirical Analysis. Modern Economy, 10, 412-428.

https://doi.org/10.4236/me.2019.102028

Received: January 4, 2019

Accepted: February 10, 2019

Published: February 13, 2019

Copyright $\odot 2019$ by author(s) and Scientific Research Publishing Inc. This work is licensed under the Creative Commons Attribution International License (CC BY 4.0).

http://creativecommons.org/licenses/by/4.0/

\section{(c) (i) Open Access}

\begin{abstract}
This paper examines the trade promoting effects of monetary union in the context of the CFA franc zone. Using the gravity model as a basis for predicting the volume of trade between countries, the study attempts to estimate the potential for increased trade within the CFA franc zone. The study shows that the CFA countries have experienced relatively low monetary growth, relatively strict budgetary disciplines, and consistently low inflation. However, the results of the study indicate that monetary union in the case of the CFA franc zone did not promote economic integration among member countries in the form of expanded trade. The actual trade among these countries remained small despite the use of common foreign exchange policy and free transferability of resources among these countries.
\end{abstract}

\section{Keywords}

Regional Integration, Monetary Union, FCFA, Model of Gravity, Commercial Potentialities

\section{Introduction}

The Franc Zone brings together fourteen African countries, grouped into two economic and monetary unions $\left(\mathrm{WAEMU}^{1}\right.$ and $\mathrm{EMCCA}^{2}$ and the Comoros ${ }^{3}$, linked to France by financial cooperation agreements. It is administered by two central banks, one for each monetary union [1]. The Central Bank of West African

${ }^{1}$ West African Economic and Monetary Union includes Benin, Burkina Faso, Côte d'Ivoire, Guinea Bissau, Mali, Niger, Senegal and Togo)

${ }^{2}$ The Economic and Monetary Community of Central Africa includes Cameroon, Central African Republic, Chad, Congo, Equatorial Guinea and Gabon).

${ }^{3}$ We will not talk about Comoros here. 
States is the common bank of the countries of the West African Economic and Monetary Union while the Central Bank of Central African States is the common bank of the countries of the central African countries. Each Central Bank creates a CFA currency different from each other. The franc of the African financial community refers to the currency of the eight West African states and the franc of financial cooperation in Central Africa to the six other countries of Central Africa. The parity of the two CFA franc vis-à-vis the French franc remained unchanged from 1948 to 1994 (50 FCFA for one French franc). A single devaluation occurred on January 12, 1994 bringing the parity to 100 FCFA for one French franc.

In the Monetary Cooperation Convention between the Member States of the Central Bank of Central African States and the French Republic of 23 November 1972, as well as in the Cooperation Agreement between the Member States of the West African Monetary Union and the French Republic of December 4, 1973, four founding principles were enunciated. It is:

$>$ Convertibility guaranteed by the French Treasury. The convertibility of the currencies issued by the various issuing institutes of the Franc Zone is guaranteed without limit by the French Treasury.

$>$ The fixity of the parities. The currencies of the Zone are convertible with each other, at fixed parities, without limitation of amounts.

Free transferability. Transfers are, in principle, free within the zone, be they current transactions or capital movements. But recently member countries impose capital controls on intra-zone transactions.

$>$ The centralization of foreign exchange reserves. In return for the unlimited convertibility guaranteed by France, the central banks of the CFA Zone are required to deposit at least $65 \%$ of their foreign exchange reserves (with the exception of the sums required for their current cash position and those relating to their transactions. with the International Monetary Fund) from the French Treasury, on the account of operations opened on behalf of each of them. This initial provision has been reduced for the BCEAO to 50\% since the 2005 reform and to 60\% (in July 2007) and 50\% (in July 2009) for the BEAC. Since 1975, these assets benefit from a foreign exchange guarantee vis-à-vis the DTS.

Devaradjan and Melo [2] [3] argue that the criterion of convertibility is particularly important for developing countries. Indeed, it is widely accepted that full convertibility has a positive international advertising effect and a disciplinary effect on macroeconomic policy; the reduction in the resulting uncertainty is necessary for the massive inflow of foreign investment ${ }^{4}$.

On 1st January 1999, the euro became the currency of eleven European members countries of the European Economic and Monetary Union (EMU) and the French franc became a non-decimal subdivision of the euro. The euro replaced the French franc as monetary anchor of the CFA franc. This substitution auto-

${ }^{4}$ For the various reasons slowing down capital flight to poor countries (where the assumption of diminishing returns will require a higher return), see Lucas (1990). 
matically determined the euro parity of the CFA franc. It does not affect the monetary cooperation mechanisms of the Franc Zone ${ }^{5}$.

The peg to the euro did not result in a change in the parities of the CFA franc. On 31 December 1998, the Council of the European Union set the irrevocable conversion rate between the euro and the French franc ( 1 euro $=6.55957$ FRF). This rate automatically determined the value of the euro in the CFA franc. As the CFA franc traded in French francs at the rate of 100 FCFA for a FRF 1, the parity of the CFA franc is now 1 euro $=655,957$ FCFA.

The general objective of this study is to capture the impact of monetary union in force in the countries of WAEMU and EMCCA on bilateral trade flows in the context of development of trade (Appendix).

The article is organized as follows. Section 1 surveys economic performance and institutional structure of the CFA area. Section 2 sketches an econometric model. Section 3 presents and analyses the results of estimation.

\section{Economic Performance and Institutional Structure of the CFA Franc Area}

Membership in a monetary union could influence trade since it implies a reduction of the uncertainty of the exchange rate [4] [5], transaction costs [6] and simplifies costing and pricing decisions [7]. More generally, if we refer to the functions of money, it appears that a common currency facilitates trade both in its function of unit of account and means of exchange. It is therefore likely that a monetary union will strengthen the flow of trade within the zone.

The ex-post analysis of the effects of monetary unions has been the subject of much empirical work. So Rose [8] [9], from a panel data study covering 186 countries in the period 1970-1990 showed that countries adopt a common currency have a trade volume significantly higher (from the order of three) compared with countries each issuing their own currency. Similarly, Frankel and Rose [10] indicate that the effects of a monetary union imply, beyond the growth of the bilateral trade, an increase in the overall opening rate, i.e. a net trade creation. Overall, the existence of a monetary union would have a positive effect on economic growth. Many other studies of currency unions generally emphasize the benefits and costs of using a common currency and common monetary policies [2] [8] [11] [12] [13].

Alesina, Barro and Tenreyro [14] [15] highlight the positive impact of currency unions on bilateral trade. They also highlight the significant influence of currency unions on the correlation between price movements in member countries. On the other hand, the existence of an effect resulting in a stronger correlation of business cycles in currency unions was not found.

Other more recent work focuses on experiences of monetary integration in Africa. Thus, Carrère [16] studies the impact of African regional agreements, with or without currency unions, using a gravity model, applied to panel data for ${ }^{5}$ The Council of the European Union, by a decision of 23 November 1998, confirmed that France could "Maintain agreements on exchange rate issues that currently bind it to WAEMU, EC MAC and Comoros" (Article 1 of the Council Decision). 
the period 1962-1996. The existence of a monetary union seems to increase in a particularly important way the intensity of the bilateral trade between the member countries ${ }^{6}$. In addition, the Carrère study highlights the trade creation and diversion effects inherent in regional trade agreements.

Moreover, Tsangarides, Ewenczyk and Hulej [17] establish that the positive effects of membership in a monetary union are not region-specific and affect both Africa and the rest of the world. Moreover, they indicate that monetary unions induce a net creation of trade and a stability of the exchanges. At the same time, they favor the correlation of price movements, without affecting the covariance of outputs.

However, when a country is a member of a monetary union, it loses its monetary independence. It therefore follows that the costs of monetary union will be measured in terms of:

- Loss of the exchange rate instrument as an adjustment variable and;

- Loss of seigniorage.

What about in the WAEMU and ECCAS zones? The CFA zone countries experienced relatively slow monetary growth, strict fiscal discipline and lower inflation than other African countries. Over the period 1970 to 1990, the rate of inflation averaged $7.3 \%$ per year compared to $18.4 \%$ a year for other African countries south of the Sahara (World Bank, World Tables). A study by Devarajan and Melo [2] shows that during the 1960s and 1970s African countries members of the franc zone improved their economic performance vis-à-vis non-CFA countries. Ten CFA zone member countries saw annual growth rates of around $4.2 \%$. These countries exported products to the world market at prices that generated gains that helped fund their development projects. At the same time, during this period exports were competitive because the French franc was depreciated against the dollar. Assane and Pourgerami [18], however, show that during this same period, other African countries south of the Sahara were also able to have high growth rates without necessarily losing their monetary autonomy.

Despite a fairly low domestic inflation, the fixed exchange rate of the CFA franc vis-à-vis the French franc is seen by some critics as being at the origin of the external competitiveness of the member states of the zone [11] [19]. The financial benefits provided by the common foreign exchange reserve are offset by the exchange rate risk and the interest rate differential between those offered by the Central Bank and the global rate. States with positive operating accounts and a high percentage of off-trade CFA trade lost the most. This is the case for most UEMOA countries where almost all countries are net losers-particularly Niger, Togo and Burkina Faso. These authors conclude that there are more losers than winners in the CFA zone.

However, greater attention was paid to the relative performance of CFA countries in the 1980s and 1990s. GDP growth rates fell below those of ${ }^{6}$ The coefficients found are of the order of 3.25 for the ECCAS and 3.13 for the WAEMU (against 0.22 for the ECOWAS). 
sub-Saharan African countries outside the zone. CFA [20]. This period corresponds to the oil crisis and the deterioration of the terms of trade. Devarajan and Melo [3] note that the lack of adjustment to the external environment has given way to some misalignment of the exchange rate and a lower economic performance. On the other hand, Medhora [21] points out that the poor performance of the 1980s can be attributed in part to poor loan practices and inadequate supervision. During this period, the French franc was strongly appreciated in order to maintain its position in the European Monetary Union. This strong French franc policy (pursued by the French government of the time) negatively affected the African economies of the CFA franc zone because they had to pay more for their imports.

The central question is whether the CFA franc zone has contributed significantly to the promotion of the economic integration of its member countries in the direction of the development of their trade and the flow of cross-border investment. Studies of integration patterns in Africa reveal that inter-regional trade has not only been insignificant but almost stationary [22] [23]. Sub-Saharan African exports accounted for only $2.8 \%$ of total exports in the Africa region and $7.1 \%$ in 1992. Inter African imports accounted for $5.8 \%$ of the total in 1984 and $7.3 \%$ in 1992 [24]. The direction of the trade matrix of the CFA zone countries also shows the same thing. Except for three countries (Burkina Faso, Mali and Chad), inter-African imports hardly exceed $10 \%$ of total imports [25].

Other studies [26] argue the contrary, highlighting the fact that the inter-African trade potential is enormous. However, these studies still recommend more trade liberalization and accelerated economic cooperation to realize this potential.

In this work, we are interested in only one of the factors, that of the impact of the monetary union in the promotion of bilateral trade between the countries members of the CFA franc zone. In addition to the standard factors affecting trade, the study will try to estimate the determinants of bilateral trade within the countries of the CFA franc zone.

\section{The Econometric Model}

There are several techniques and methods for evaluating regional trade ${ }^{7}$. Among these is the gravity model. This is a simple tool and often gives very good results in predicting bilateral trade volumes. Inspired by Newton's theory ${ }^{8}$, the gravity model expresses trade flows between two countries as proportional to their economic weight and inversely proportional to the geographical distance separating them.

${ }^{7}$ These include monitoring of macroeconomic indicators such as growth and inflation [27], flows revealed commercial advantages and comparative advantages [28] [29], etc.

${ }^{8}$ Newton's theory of gravitation refers to a physical law according to which the gravitational force between two objects is proportional to their respective masses and inversely proportional to the square of the distance between these two objects. 


\subsection{Theoretical Foundations and Empirical Justification of the Gravity Model}

The gravity model is a generic name for the family of quantitative models developed by the astronomer Stewart in 1940 [38]. Since the 1960s, this model has had wide empirical success. Despite this state of affairs, the model has suffered for several years economically from theoretical foundations. The many forms of equation that have followed one another in the empirical literature can be explained by the absence of a consensual theory [30] [31] [32] [33] [34]. Thanks to a recent wave of theoretical work, the gravity model has shifted from an embarrassment of poverty from theoretical foundations to an embarrassment of richness of theoretical origins [29]. Despite the continuing discussions, it is now recognized that the theoretical underpinnings of the gravity model are justified by microeconomic considerations [30] [32] [35], by theories of international trade [31] [36] [37] and finally by the new geographical economy [38]. For example, Bergstrand [36] derives the gravitational equations for differentiated products by implicitly relying on Ricardian, Heckscher-ohlin and increasing efficiency models.

As we can see and as Martinez-Zarzoso and Nowak-Lehmann [39] say, the theoretical support for this model was originally poor and it was not until the mid-1970s that many theoretical developments emerged as the basis the gravity model. If the first attempt at theoretical explanation was given by Anderson [35], who derived the expression of gravity from a model that assumes the differentiation of products, other work consisted not only in strengthening the prior theoretical framework but also to propose other extensions. These include, among others, Bergstrand [36], Helpman [40], Oguledo and MacPhee [37] [41] Deardorff [37], Hummels and Levinsohn [42], Anderson and Wincoop [43].

The work of these authors consisted in taking into account two main determinants that characterize the models of the new theory of trade, namely: economies of scale combined with product differentiation and transport costs.

Empirically, the gravity model has proved to be a particularly useful tool for analyzing bilateral trade between countries [44]. Moreover, since Rose [8], the properties of the gravitational model have been used to evaluate the effects of monetary unions, in particular their impact on trade [10] [15] [44].

While the applications of the gravity model are numerous in Europe and Latin America [27] [45] [46], they are quite rare in African countries. Foroutan and Pritchett [21] were the first to apply an improved version of this model to Sub-Saharan African (SSA) countries in order to quantify the level of potential intra-SSA trade and to compare it with the level of current. The results of the work of Foroutan and Pritchett [21] confirm that, in general, the observed intra-ASS trade (current) is weaker than expected. The reasons are, according to these authors of structural order9. Other authors like Naudet [47], think rather that the low level of exchanges result from the fact that the countries of the re-

${ }^{9}$ For all 19 SSA countries, the average proportion of intra-SSA imports observed was 3.5\% compared to $3.6 \%$ predicted by the model. For exports the figures were $4.6 \%$ and $3.9 \%$. 
gion do not fully exploit their commercial potential. For the latter trade West Africa to take this example could represent $25 \%$ of total trade by 2020 .

In order to circumscribe intra-African trade, Elbadawi [48] will also use the traditional gravity model by including in his sample some African regional groupings. He insists particularly on the impact of currency unions on the flow of regional trade. This work is in line with those made by Rose [8] [9]. The latter author has shown that at comparable levels of development the countries belonging to a monetary union would trade 3.3 times (e1, $2=3.3$ ) more than those with their own currency. This result will be nuanced by that obtained by Nitsch [49] on the same sample but corrected by multiple variations 10. Longo and Sekkat [50] show that, except for the traditional variables of the gravity model, poor infrastructure, mismanagement of economic policy, and internal political tensions have a negative impact on trade between African countries. Looking at the period 1962-1996 in the context of an improved gravity model, Carrère [15] uses the Hausman-Taylor method to show that African regional trade agreements have generated a significant increase in trade between member countries. Musila [51] in the case of COMESA (Common Market for Eastern and Southern Africa), ECCAS (Economic Community of Central African States) and ECOWAS (Economic Community of West African States) finds that the intensity of trade creation is stronger in the ECOWAS countries followed by those of COMESA. Avom [52], in the case of CEMAC, also used the Hausman-Taylor estimator [53], as part of an improved gravity model, to reveal that participation in the monetary union did not take place very little effect on regional trade.

Other interesting work has been done [15] [54] [55] [56] [57]. Most of them with appreciable results confirming the advantage of the gravity model over other methods, but these results differ each other for reasons of choice of estimation techniques, variables and objectives.

The originality of our work compared to the studies carried out lies in the empirical approach adopted. The study is based, in this case, on the estimation of a gravity model, intended to circumscribe the determinants of bilateral trade between WAEMU and ECCAS member countries and especially to capture the commercial potentialities of within these two groups since the implementation of the two currency unions in the mid-1990s.

\subsection{Specification of the Model}

Empirical analysis is based on an augmented form of the traditional gravity model. The use of this augmented model makes it possible to determine the effect of distance and belonging to the same monetary zone on the intensity of trade between CFA Franc Zone member countries. This distance is usually measured between the economic centers or capitals of the two countries considered. Formally, the gravity equation, in its simplest form, is given by:

$$
X_{i j}=A *\left(Y_{i} Y_{j} / D_{i j}\right)
$$

where $X_{i j}$ represents the value of trade flows (for example, exports) between a 
country $i$ and a country $j, Y$, their national income, $D_{i j}$ a measure of the distance between these countries and $A$, a coefficient of proportionality. It is generally estimated in logarithmic form. In addition to the traditional variables of GDP and distance, various variables have been added to this basic formulation in order, among other things, to capture certain specificities of the bilateral relationship: the sharing of a land border, the effect of the oil and cotton countries. . The per capita GDP variable has also been introduced to measure the level of development of each country, as it is assumed that as a country develops, it tends to become more specialized, and to trade more [28]. The effect of the monetary union on trade is measured using the method used in the article by Rose [8] which introduces into the traditional gravity equation an indicator variable which takes the value 0 for countries who have their own currency, and the value 1 for member countries of a monetary union.

A positive relationship between GDP and trade is expected. Transport costs are usually captured by the distance between co-traders, to which are added dummy variables relating to the isolation and/or sharing of common borders by the economies of the grouping. The sharing of a common border is measured by a binary variable equal to unity when countries $i$ and $j$ share a common border and to zero otherwise. Contiguity is expected to have a positive impact on bilateral trade. A priori we can say that distance has a negative correlation with the volume of trade.

The estimated gravity equation is:

$$
\begin{aligned}
\log \left(\text { XIJCOR }_{i j}\right)= & \beta_{0}+\beta_{1} \log \left(G D P_{i} * G D P_{j}\right)+\beta_{2} \log \left(G D P T_{i} * G D P T_{j}\right) \\
& +\beta_{3} \log \left(D_{i j}\right)+\beta_{4} U M_{i j}+\beta_{5} \log L A N D \\
& +\beta_{6} \operatorname{OIL}_{i j} \beta_{7} \operatorname{COTON}_{i j}+\varepsilon_{i j}
\end{aligned}
$$

where $X I J C O R_{i j}$ is the flow of exports between countries $i$, and $j$ at period $t$,

$G D P$ is the total real $G D P$,

$G D P T$ is the real GDP per capita,

$D_{i j}$ is the distance between $i$ and $\mathrm{j}$ from the CEPII website.

$\mathrm{UM}$ is a dummy variable that is 1 , when $i$ and $j$ share the same currency area. She is broken down into WAEMU and Customs and Economic Union of Central Africa during the period from 1990 to 1994, and into UEMOA and ECCAS, over the period from 1994 to 2006.

$L A N D$ is a dummy variable that is 1 , if $i$ and $j$ share a border.

$O I L$ is a dummy that takes into account the oil producing countries, COTTON is a dummy that takes into account cotton countries, $\mathcal{E}_{i j}$ is the error term.

\section{Presentation and Analysis of Results of Estimation}

The sample taken into account includes all eight (8) WAEMU countries and all six (6) CEMAC countries.

The augmented gravity equation was estimated on panel data using non-effects 
GCMs with heteroskedasticity correction. The estimator used is CPSE (Panel Cross Section Error). The results obtained were more robust than those obtained with GCMs with fixed and random effects. The sample comprises 2358 observations, from 1990 to 2006. The variable dependent is the flow of exports. The sample was divided into two sub-periods (1990-1994 and 1995-2006) before and after the reforms. There is no missing data. For each of the sub-periods, we average the data in order to avoid the cyclical biases (business cycle) that sometimes occur when the estimates are made for a year.

The interest of this division is twofold. The first period takes into account the effect of the structural adjustment programs applied in several economies of the subregion. During this period it is estimated that SAPs are assumed to have affected the structure and trend of production and trade of these economies. The second period makes it possible to test changes in the institutions of the CFA zone countries with the advent of UEMOA and CEMAC. For each of the two periods we measure the flow of exports as the volume of imports from country $i$ as recorded in country $\mathrm{j}$. In doing so this measure takes into account transport costs since imports are recorded in CIF value (freight insurance costs). Moreover, the choice of imports in place of exports or total trade (imports + exports) takes into account the quality as well as the availability of data. Indeed, the data relating to imports are generally reported with more precision, with regard to the duties and taxes to be collected [15]. In addition, the available information does not distinguish between cases or exports to a given country are zero cases where they are not reported. As a result, the summation of imports and exports could lead to biased results.

The data for this study (annual exports and imports) are in constant millions of US dollars from 1988 and come from the IMF's "Direction of Trade" and the World Bank's “African Development Indicators”. Data for real and per capita GDP cover the period from 1990 to 2006, which is 17 years. They are extracted from the World Bank Economic and Social Data Bank (ESDP) and AfDB African Development Reports. GDP in constant millions of US dollars in 1988 is at market price and GDP per capita is the standard of purchasing power. Data on the distance (in kilometers) between the coexchangers comes from the CEPII website (Center for Prospective Studies and International Information) (Table A1 in Appendix).

One of the characteristics of trade between African countries is the scarcity of data for a large number of bilateral relations. Thus, the value of trade between two countries can be zero. With a specification in logarithm, such an observation will become indeterminate. To solve this problem, there are two possibilities. Zero values can be eliminated if their percentage in the observations is small and subsequently used the ordinary least squares (OLS) method for estimating the model. If the proportion of nil observations is high, the use of OLS leads to biased results. This can be verified by averaging the error term. It is common in this case to use a non-linear estimation technique such as Tobit, which explicitly recognizes the existence of the null values of the dependent variable and treats 
them as non-registered trade flows while normalizing the distribution. In addition, if estimating from a Tobit is not a problem, the measurement of the model's performance is not the subject of a consensus. The measure generally used in the literature, Pseudo-R2, comes in several forms (Veall and Zimmermann, 1994). We use in this work the Mac Fadden Pseudo-R2 which is the most widespread. The results of the estimates for the two sub-periods are summarized in Tables.

The results of our estimates are presented in Table 1 and Table 2.

\subsection{0-1994 Period}

This phase corresponds to the period during which most of the CFA zone countries have been applying (for some years) structural adjustment programs following macroeconomic imbalances. The results obtained above (Table 1) show that the estimates made over the period 1990-1994 are quite robust.

The explanatory power of the model is $94.3 \%$, and the model is globally significant. All variables except GDP per capita are significantly different from zero. The estimates obtained are consistent with the empirical results obtained in previous work. The remoteness of two countries reduces trade by $0.73 \%$, while increases in real GDP and GDP per capita intensify them. The sharing of a common border is also one of the determining factors that explains the increase in bilateral trade. GDP and monetary union dummy variables (CEMAC, UEMOA) and the common border (Land) contribute most to the increase in export flows. The Countries in the Franc Zone with a common border trade three times more than other countries.

In addition, the results show that bilateral trade increases in the WAEMU zone (ex CEAO) by 22.27 times and in the CEMAC zone (formerly UDEAC) by 3.28 times. In other words, trade in the WAEMU zone is 6.78 times more intense than in the CEMAC zone (see Table A2 in Appendix).

The analysis of IMF statistics confirms the results obtained. During this sub-period, the share of intra-zone trade in UEMOA's total trade is greater than in the CEMAC zone. This is between $8 \%$ and $11 \%$ in the UEMOA, while in the CEMAC zone, it fluctuates between $0.90 \%$ and $3.51 \%$. In view of these results, it can be said that the objective of CEAO, which was, inter alia, to promote trade between these countries in response to market problems, has been achieved.

Oil producing countries trade more with each other than cotton producers. In the 1990-1993 sub-period, trade between oil-producing countries increased by $1.38 \%$, while that of cotton producers increased by only $0.87 \%$. This can be explained by the fall in export prices of agricultural commodities (especially cotton) during this period, following the deterioration of the terms of trade and the competitive devaluation policies of neighboring countries not belonging to the region, not at the CFA zone.

\subsection{Period 1994-2006}

During the sub-period 1994-2006, we add to the gravitational model CEMAC, UEMOA, LAND, OIL and COTON indicator variables to take into account the 
Table 1. Estimation of gravitational model over the period 1990 to 1994.

\begin{tabular}{ccccc}
\hline Variable & Coefficient & Std Error & t-Statistic & Prob. \\
\hline LOG (GDPT ${ }^{*}$ GDPTJ $)$ & 0.01392 & 0.035568 & 0.393403 & 0.6941 \\
LOG (GDP ${ }^{*}$ GDPJ) & 1.615040 & 0.032530 & 49.647756 & 0.0000 \\
LOG (DIJ) & -0.313629 & 0.044400 & -7.063712 & 0.0000 \\
CEMAC & 1.189252 & 0.122967 & 9.671322 & 0.0000 \\
UEMOA & 3.103593 & 0.107086 & 28.98220 & 0.0000 \\
LAND & 1.126699 & 0.049398 & 22.80879 & 0.0000 \\
OIL & 0.324932 & 0.051422 & 6.318905 & 0.0000 \\
COTON & -0.138655 & 0.053643 & -2.584746 & 0.0000 \\
C & -69.45806 & 1.264201 & -54.94226 & 0.0000 \\
\hline R-squared & 0.943751 & Mean dependantvar & 3.499024 \\
Adjusted R-quared & 0.943421 & S.D dependantvar & 8.368707 \\
S.E of regression & 1.990615 & Akaike info criterion & 3.269740 \\
Sum squared resid & 5393.029 & Schwarz criterion & 3.304048 \\
Log likelihood & -2230.772 & F-statistic & 2854.389 \\
Durban-Watson stat & 0.779621 & Prob (F-statistic) & 0.000000 \\
\hline
\end{tabular}

Dependant Variable: LOG (XIJCOR). Method: Pooled Least Squares. Cross-sections included: 128. Total pool (unbalanced) observations: 1370. Cross-sections weight (PCSE) standard error \& covariance (no d.f. correction).

Table 2. Estimation of the gravitational model over the period 1994 to 2006.

\begin{tabular}{ccccc}
\hline Variable & Coefficient & Std Error & t-Statistic & Prob. \\
\hline LOG (GDPT ${ }^{\star}$ GDPTJ) & 0.306791 & 0.081800 & 3.750511 & 0.0002 \\
LOG (GDP*GDPJ) & 0.177142 & 0.037080 & 4.779879 & 0.0000 \\
LOG(DIJ) & -1.722398 & 0.143974 & -11.96325 & 0.0000 \\
CEMAC & -0.907120 & 0.263532 & -3.442161 & 0.0000 \\
UEMOA & 1.723006 & 0.221905 & 7.764623 & 0.0000 \\
LAND & 1.431575 & 0.197897 & 7.233932 & 0.0000 \\
OIL & 1.029275 & 0.224676 & 4.581159 & 0.0000 \\
COTON & -0.945737 & 0.205389 & -4.604605 & 0.0000 \\
C & 0.306791 & 0.081800 & 3.750511 & 0.0002 \\
R-squared & 0.432972 & Mean dependantvar & -0.061212 \\
Adjusted R-squared & 0.428922 & S.D dependantvar & 3.080335 \\
S.E of regression & 2.327800 & Sum Squared resid & 5310.281 \\
F-statistic & 106.9014 & Durbin-watson stat & 0.272418 \\
Prob (F-statistic) & 0.000000 & & \\
\hline
\end{tabular}

Dependant Variable: LOG (XIJCOR). Method: Pooled Least Squares. Cross-sections weight (PCSE) standard error \& covariance (no d.f. correction). 
effect of the different monetary zones, borders and oil and cotton producing countries. The Franc Zone on bilateral trade. The quality of the adjustment evaluated by the coefficient of determination R2 indicates that $43 \%$ of the fluctuations in exports are explained by the model. All the coefficients associated with the estimated variables are significantly different from zero. The model is globally significant. The introduction of LAND, OIL and COTTON variables in the model shows that the flow of exports does not depend only on the traditional variables of the gravity model. Trade increases by $4.17 \%$ more in countries sharing a common border than in other Franc Zone countries, and the effect of distance on the exogenous variable decreases by half (Table 2).

In addition, GDP in countries $i$ and $j$ positively explains trade flows between them. When GDP increases by $1 \%$, the flow of exports increases by $0.1 \%$. The introduction of CEMAC and UEMOA dummy variables indicates that belonging to a common currency area has a positive effect on bilateral trade. The countries of the WAEMU zone trade 13.87 times more than the countries of the CEMAC zone.

However, the effect of currency areas is not the same. One could conclude that the formation of monetary and economic unions in both zones has only a negligible effect on bilateral intra-zone trade. Beyond the facilitation of the circulation of goods and services, the objective of the creation of these institutions is to catalyze exports, in general, and intra-zone trade, in particular. Bilateral trade among oil-producing countries is increasing by $2.8 \%$, while cotton producing countries have grown by $0.38 \%$.

These results conceal the weakness of intra-zone trade. According to the IMF, intra-WAEMU trade is still hampered by significant non-tariff barriers (national standards, quantitative restrictions on certain imports, treatment discrimination of national and regional products, etc.). As for the CEMAC zone, the preferential tariff adopted in 1994 on intra-Community trade is applied unequally.

As can be seen in the sub-periods under consideration, the oil producing countries trade more with each other than the cotton producing countries, certainly because most of these countries are landlocked.

\section{Conclusions}

The purpose of this paper was to analyze the impact of currency unions on bilateral trade.

From an overall point of view, the main expected effects of the adoption of a common currency and monetary policy fall into two main areas. On the one hand, the reduction in transaction costs related to currency differences allows the expansion of trade and the growth of activity. On the other hand, the strengthening of the credibility of the Monetary Authority resulting from its regional status contributes to the stabilization of the macroeconomic framework.

On the trade side, most ex-ante analyzes have highlighted the weakness of intra-regional trade potential, mainly related to structural barriers. 
Based on gravitational models, this study has attempted to highlight the determinants of bilateral trade and, in particular, the impact of the existing monetary union, in this case UEMOA and CEMAC.

It thus appeared that the geographical and structural factors, but also the membership of the monetary union, determine the intensity of bilateral trade flows within these two unions. In addition, the impact of the common currency is reflected in significant trade creation.

However, the potential for intra-regional trade could be strengthened by putting more emphasis on the structural reforms needed to diversify economies and thus promote complementarities, develop infrastructure and enhance convergence of macroeconomic performance and policies.

In a panel of bilateral trade between CEMAC and WAEMU countries over the period analysed, it appears that economic size, geographical and political factors are the major drivers of bilateral trade between UEMOA and CEMAC members countries. More importantly, our results show that a generalized model which includes all the possible dimension of trade effects (both the main and interaction effects) is more appropriate for the analysis of bilateral trade in UEMOA and CEMAC. Therefore, ignoring any of these effects gives misleading inferences as suggested by the results of the analysis carried out.

In terms of policy implications, we recommend that concerted efforts should be geared at increasing the productive capacity and value addition in countries in the ECOWAS region. This will not only promote trade and output but result into more employment opportunities, increased revenue and attract the much needed capital inflow into the region. Also, despite the fact that infrastructure is inevitable for growth in intra-regional trade; it is currently insufficient and dilapidating in nature in ECOWAS as a whole. This calls for adequate attention. Giving the importance of political stability to trade, we recommend that all stakeholders should strive for the prevention and prompt resolution of conflict and political instability in the region. Finally, analysis of bilateral trade in UEMOA and CEMAC should always take cognizance of all the dimensions of the panel, especially since countries in the region differ or change over time and space.

\section{Conflicts of Interest}

The author declares no conflicts of interest regarding the publication of this paper.

\section{References}

[1] Hallerberg, E.W. and Ozden, C. (2000) Monetary Union Institutional Structure and Commitment, The CFA. Emory University, Miméo.

[2] Devarajan, S. and De Melo, J. (1987) Evaluating Participation in African Monetary Unions: A Statistical Analysis of the CFA Zones. World Development, 15, 483-496. https://doi.org/10.1016/0305-750X(87)90115-X

[3] Devarajan, S. and de Melo, J. (1991) Membership in the CFA Zone: Odyssean Journey or Trojan Horse? Conference on African Economic Issues, Nairobi. 
[4] Clark, P. (1973) Uncertainty, Exchange Risk and the Level of International Trade. Western Economic Journal, 11, 303-313. https://doi.org/10.1111/j.1465-7295.1973.tb01063.x

[5] Hooper, P. and Kohlhagen, S. (1978) The Effects of Exchange Rate Uncertainty on the Prices and Volume of International Trade. Journal of International Economics, 8, 483-511. https://doi.org/10.1016/0022-1996(87)90001-8

[6] Commission Européenne (1990) One Market, One Money. European Economy 44.

[7] Kenen, P. (2003) Five years of the ECB, Centre Piece. The Magazine of Economic Performance, 8, 31-36.

[8] Rose, A.K. (2000) One Money, One Market and the Effect of Common Currencies on Trade. Economic Policy, 15, 7-45. https://doi.org/10.1111/1468-0327.00056

[9] Rose A.K. (2002) Honey, The Currency Union Effects on Trade: Hasn't Blown Up. The World Economy, 25, 475. https://doi.org/10.1111/1467-9701.00444

[10] Frankel, J. and Rose, A. (2002) Estimating the Effect of Currency Unions on Trade and Output. Quarterly Journal of Economics, No. 117 (2).

[11] Allechi, M. and Niamkey, M.A. (1994) Evaluating the Net Gains from the CFA Franc Zone Membership: A Different Perspective. World Development, 22, 1147-1160. https://doi.org/10.1016/0305-750X(94)90082-5

[12] Cobham, D. and Robson, P. (1994) Monetary Integration in Africa: A Deliberately European Perspective. World Development, 22, 285-299. https://doi.org/10.1016/0305-750X(94)90122-8

[13] Glick, R. and Rose, A.K. (2002) Does a Currency Union Affect Trade? The Time Series Evidence. European Economic Review, 46, 1125-1151. https://doi.org/10.1016/S0014-2921(01)00202-1

[14] Alesina, A. and Barro, R.J. (2002) Currency Unions. Quarterly Journal of Economics, No. 117.

[15] Alesina, A., Barro, R.J. and Tenreyro, S. (2002) Optimal Currency Areas. NBER, Working Paper, No. 9072.

[16] Carrère, C. (2004) African Regional Agreements: Impact on Trade with or without Currency Unions. Journal of African Economies, 13, 199-239. https://doi.org/10.1093/jae/ejh010

[17] Tsangarides, C.-G., Ewenczyk, P. and Hulej, M. (2006) Stylised Facts on Bilateral Trade and Currency Unions: Implications for Africa. IMF Working Paper, $\mathrm{WP} / 06 / 31$

[18] Assane, D. and Pourgerami, A. (1994) Monetary Cooperation and Economic Growth in Africa: Comparative Evidence from the CFA Zone Countries. Journal of Development Studies, 30, 423-442. https://doi.org/10.1080/00220389408422322

[19] Hadjimichael, M.T. and Galy, M. (1997) The CFA Franc Zone and the EMU. IMF Working Paper (WP/97/156), Washington DC.

[20] World Bank (1998) World Development Report 1997. World Bank, Washington DC.

[21] Medhora, R. (1993) Monetary Integration in West Africa: Lessons from the Integration.

[22] Foroutan, F. and Pritchett, L. (1993) Intra-Sub-Sahara African Trade: Is It Too Little. Policy Research Working Paper No. 1225, The World Bank Policy Research Dept, Trade Policy Division.

[23] Lyakurwa, N.M. (1993) Trade Policy and Promotion in Sub-Saharan Africa. Special 
Paper No. 12, African Economic Research Consortium, Nairobi.

[24] IMF (1991, 1993) Direction des Statistiques. Washington DC.

[25] UNDP and World Bank (1992) Africa Development Indicators. World Bank World Bank, Washington DC.

[26] Oramah, B.O. and Abou-Lehaf, C. (1998) Commodity Composition of African Trade and Intra-African Trade Potential. Journal of African Economies, 7, 263-300. https://doi.org/10.1093/oxfordjournals.jae.a020951

[27] Wang, L.A. and Winters, L.A. (1991) The Trade Potential of Eastern Europe. Journal of Economic Integration, 7, 113-136. https://doi.org/10.11130/jei.1992.7.2.113

[28] Yeats, A. (1998) What Can Be Expected from African Regional Trade Arrangement? Some Empirical Evidence, Policy Research Working Paper No. 2004, World Bank, Washington DC.

[29] Frankel, J. (1997) Regional Trading Blocks in the World Economy. Institute for International System, Institute for International Economics, Washington DC. https://doi.org/10.7208/chicago/9780226260228.001.0001

[30] Tinbergen, J. (1962) Shaping the World Economy, Suggestions for an International Economic Policy. The Twentieth Century Fund, New York.

[31] Pöyhönen, P. (1963) A Tentative Model for the Flow Trade between Countries. Weltwirtschafitiliches Archiv, Band 90, heft 1.

[32] Linneman, H. (1966) An Econometric Study of International Trade Flows.

[33] Aitken, N.D. (1973) The Effect of EEC and EFTA on European Trade: A Temporal Cross Section Analysis. American Economic Review, 63, 881-892.

[34] Sapir, A. (1981) The Trade Benefits under EEC Generalized System of Preferences. European Economic Review, 15, 339-355.

[35] Anderson, A. (1979) A Theoretical Foundation for the Gravity Model. American Economic Review, 63, 881-892.

[36] Bergstrand, J.H. (1985) The Gravity Equation in International Trade: Some Microeconomic Foundations and Empirical Evidence. Review of Economics and Statistic, 67, 474-481. https://doi.org/10.2307/1925976

[37] Deardorff, A.V. (1995) Determinants of Bilateral Trade: Does Gravity Work in a Neo-Classic World? National Bureau for Economic Research Working Paper 5377.

[38] Stewart, J.Q. (1940) Suggested Principles of Social Physics, Science, 106, 179-180.

[39] Martinez-Zarzoso, I. and Nowak-Lehmann, F. (2003) Augmented Gravity Model: An Empirical Application to MERCOSUR-EU Trade Flows. Journal of Applied Economics, 6, 291-316. https://doi.org/10.1080/15140326.2003.12040596

[40] Helpman, E. (1987) Imperfect Competition and International Trade: Evidence from Fourteen Industrial Countries. Journal of the Japanese and International Economies, 1, 62-81. https://doi.org/10.1016/0889-1583(87)90027-X

[41] Oguledo, I.V. and MacPhee, C.R. (1994) Gravity Models: A Reformulation and an Application to Discriminatory Trade Arrangements. Applied Economics, 26, 107-120. https://doi.org/10.1080/00036849400000066

[42] Hummels, D. and Levinsohn, J. (1995) Monopolistic Competition and International Trade: Reconsidering the Evidence. Quarterly Journal of Economics, 110, 799-836. https://doi.org/10.2307/2946700

[43] Anderson, J.E. and Wincoop, E. (2001) Gravity with Gravitas: A Solution to the Border Puzzle. National Bureau for Economic Research Working Paper, 8079. 
[44] Smith, C. (2002) Currency Unions and Gravity Models Revisited. Reserve Bank of New Zealand, Discussion Paper Series DP 2002/07.

[45] Balassa, B. and Beuvens, L. (1988) The Determinants of Intra-European Trade in Manufactured Goods. European Economic Review, 32, 1421-1437.

[46] Eichengreen, B. and Bayoumi, T. (1995) Is Regionalism Simply a Diversion? Evidence from the Evolution of the EC and EFTA.

[47] Naudet, J.D. (1993) Modélisation des Flux d'Echanges Extérieurs Internationaux (1970-1990) et Analyse des Modèles d'Ouverture en Afrique de l'Ouest. Document de travail, $\mathrm{n}^{\circ} 13$ réalisé dans le cadre de l'étude sur les perspectives à long terme en Afrique de l'ouest, OCDE, BAD, CILSS.

[48] Elbadawi, I. (1995) The Impact of Regional Trade and Monetary Schemes on Intra-Sub-Saharan Africa Trade. In: Oyedjide, et al., Eds., Regional Integration and Trade Liberalization in Sub-Saharan Africa, Macmillan Press Ltd., London, Vol. 22, No. 8, 1147-1160.

[49] Nitsch, V. (2002) Honey, I Shrunck the Currency Union Effect on Trade. The World Economy, 25, 457-474.

[50] Longo, R. and Sekkat, K. (2004) Economic Obstacles to Expanding Intra-African Trade. World Development, 32, 1309-1321. https://doi.org/10.1016/j.worlddev.2004.02.006

[51] Musila, J.W. (2005) The Intensity of Trade Creation and Trade Diversion in COMESA, ECCAS and ECOWAS: A Comparative Analysis. Journal of African Economies, 14, 117-141. https://doi.org/10.1093/jae/ejh039

[52] Avom, D. (2005) Les Déterminants des Échanges dans la CEMAC: Une Évaluation empirique. Economie Appliquée, 58, 127-153.

[53] Hausman, J.A. and Taylor, W.E. (1981) Panel Data and Unobservable Individual Effects. Econometrica, 49, 1377-1398. https://doi.org/10.2307/1911406

[54] Cassim, R.D. and Hartzemburg, T. (1997) Trade Related Aspect of Regional Intégration in Southern Africa. Final Report, AERC.

[55] Gbetnkom, D. and Avom, D. (2005) Intégration par le marché, le cas de l'UEMOA. Région et Développement, No. 22, 85-103.

[56] Agbodji, A.E. (2007) Intégration et Échanges commerciaux Intra Sous-régionaux: Le Cas de l'UEMOA. Revue Africaine de Intégration, 1, 161-188.

[57] Diaw, D. and Tra, T.A.-D. (2009) Intégration Régionale et expansion du Commerce Sud-Sud: Le cas du Sénégal dans l'UEMOA. Revue Tiers-Monde, Armand Colin, 627-646. 


\section{Appendix}

Table A1. Source and availability of data.

\begin{tabular}{|c|c|c|c|c|}
\hline Abréviations & Description & Période & Source & Type \\
\hline XIJ & Flux de commerce bilatéral & $1990-2006$ & FMI & Endogène \\
\hline GDPi & Niveau de PIB du pays $i$ & $1990-2006$ & BAD. & Exogène \\
\hline GDPj & Niveau du PIB du pays $j$ & $1990-2006$ & BAD. & Exogène \\
\hline GDPTi & $\begin{array}{c}\text { Niveau du PIB par tête } \\
\text { du pays } i\end{array}$ & $1990-2006$ & BAD. & Exogène \\
\hline GDPTj & $\begin{array}{c}\text { Niveau du PIB par tête } \\
\text { du pays } j\end{array}$ & $1990-2006$ & BAD. & Exogène \\
\hline $\mathrm{Dij}$ & Distance entre les pays $i$ et $j$ & $1990-2006$ & CEPII & Exogène \\
\hline LAND & Frontière entre les pays $i$ et $j$ & $1990-2006$ & World Bank Data Base & Exogène \\
\hline UEMOA & Pays appartenant à l'UEMOA & $1990-2006$ & World Bank Data Base & Exogène \\
\hline CEMAC & $\begin{array}{c}\text { Pays appartenant à la } \\
\text { CEMAC }\end{array}$ & $1990-2006$ & World Bank Data Base & Exogène \\
\hline OIL & $\begin{array}{l}\text { Côte d'Ivoire, Cameroun, } \\
\text { Congo, Gabon }\end{array}$ & $1990-2006$ & World Bank Data Base & Exogène \\
\hline COTON & $\begin{array}{c}\text { Bénin, Burkina Faso, } \\
\text { Centrafrique, Mali, Niger, } \\
\text { Tchad, Togo }\end{array}$ & $1990-2006$ & World Bank Data Base & Exogène \\
\hline
\end{tabular}

Source: Own construction.

Table A2. Pairwise bilateral trade in WAEMU zone and EMCCA.

\begin{tabular}{|c|c|c|c|}
\hline UEMOA & Montant en milliards de $\$$ & CEMAC & Montant en milliards de \$ \\
\hline MALI TO BENIN & 6.58975854 & TCD TO GAB & 0.07157383 \\
\hline BENIN TO BURKINA & 20.3504369 & RCA TO CGO & 0.541544 \\
\hline MALI TO NIGER & 30.13219398 & GAB TO RCA & 4.87066152 \\
\hline NIGER TO SENEGAL & 40.02855788 & CGO TO RCA & 7.6971015 \\
\hline TOGO TO SENEGAL & 110.9322312 & TCD TO CGO & 6.999988 \\
\hline NIGER TO BENIN & 111.5991176 & TCD TO RCA & 27.821181 \\
\hline BENIN TO SENEGAL & 209.826437 & GAB TO CGO & 56.578946 \\
\hline TOGO TO BURKINA & 267.489703 & RCA TO CMR & 298.351508 \\
\hline $\begin{array}{c}\text { BENIN TO COTE } \\
\text { D'IVOIRE }\end{array}$ & 239.489703 & TCD TO CMR & 329.870896 \\
\hline $\begin{array}{l}\text { COTE D'IVOIRE TO } \\
\text { NIGER }\end{array}$ & 594.040127 & CMR TO CGO & $\begin{array}{l}436.730869 \\
659.557647\end{array}$ \\
\hline SENEGAL TO MALI & 853.7939 & CMR TO GAB & \\
\hline $\begin{array}{c}\text { COTE D'IVOIRE TO } \\
\text { TOGO }\end{array}$ & 1094.246716 & & \\
\hline SENEGAL TO COTE & 1615.276527 & & \\
\hline \multicolumn{4}{|l|}{ D'IVOIRE } \\
\hline COTE D'IVOIRE TO & 2788.337404 & & \\
\hline \multicolumn{4}{|l|}{ BURKINA } \\
\hline $\begin{array}{l}\text { MALI TO COTE } \\
\text { D'IVOIRE }\end{array}$ & 3331.885322 & & \\
\hline
\end{tabular}

